\title{
Latvian Potential in the Trade with the EU Countries
}

\author{
Ërika Pančenko ${ }^{1}$, Tatjana Ivanova ${ }^{2}$ \\ ${ }^{1,2}$ Riga International School of Economics and Business Administration
}

\begin{abstract}
The importance of international trade for the economic development of any country, on the one hand, and the decreasing rates of goods turnover within the $E U$ countries in recent years, on the other hand, reveal the relevance of the research on the assessment of Latvia's trade potential with the EU countries.

The aim of this study is to measure and assess Latvia's export potential with the European Union countries based on the gravity model.

Since the development of trade relations is influenced by various factors, the article provides an overview of empirical studies that analyse various factors determining the level of trade among the countries.

Possible volume of exports from Latvia to the EU countries was calculated on the basis of gravity model; calculations were conditioned by several factors included in the model, such as GDP, geographical distance and the degree of country's economic freedom. The article also provides an assessment of Latvia's export potential realisation extent.

The method described in this article allowed applying the gravity model for the assessment of cooperation between Latvia and the EU countries, and was suitable for the quantitative evaluation of the extent to which export potential was realised in other countries.
\end{abstract}

Keywords - Export potential, export potential realisation, gravity model.

\section{INTRODUCTION}

Latvia is a small country; therefore, its economic development depends heavily on the successful cooperation with other states.

The development of this cooperation is stimulated by the measures taken on the governmental level that are aimed at advancing external economic links and integration of Latvia into the global economy. In particular, joining the World Trade Organization (on 10 February 1999) was a significant step made by Latvia with a view to provide the country's membership in the international trade system on equal conditions with other WTO members. Also, entering the European Union (on 1 May 2004) made Latvia the full member of the united European market. Further efforts are being made by Latvia to lessen trade barriers and deepen economic relations by means of signing mutual economic partnership agreements with the third countries, as well as supporting intergovernmental committees (the Ministry of Economics of Latvia, 2014).

According to the data issued by the Central Statistical Bureau of Latvia, foreign trade turnover has been growing in Latvia to reach EUR 22903 million in 2014, which is 14.4 times more as compared with 1992. However, import still dominates in the structure of foreign trade, thus negatively affecting the trade balance and setting the need to seek for opportunities to increase the export trade flow from Latvia.

Latvia's main trading partners are the EU countries, and their part in the total volume of foreign trade of Latvia in 2014 was $77 \%$. However, in recent years, the trend has been toward reduction in trade growth between the EU, including a slowdown in export growth to these countries. Nevertheless, the growth rate of goods turnover with the EU counties has been decreasing in recent years, as well as the growth rate of exports to these countries has been going down.

Increasing export volume and developing sectors of national economy aimed at exporting their products are formulated in the plan of national development of Latvia for the period of 2014-2020 as the basis for Latvia's long-lasting economic policy. In order to solve this important problem, it is suggested both to increase market share in partner states and to explore new markets (Cabinet of Ministers of the Republic of Latvia, 2013). In this regard, the appropriate choice of goods and services export flow is the most essential task for each Latvian exporter. During the period of Latvia's membership in the European Union, quite much statistical data on mutual trade-economic activity has been collected and processed in various pieces of research.

In particular, the research papers have been devoted to the following issues: developing Latvian export to the world's states including the EU member states, in the context of national economy sectors that are export participants, and in the context of the products being exported (goods, services). As a result of the analyses that have been made, export dynamics and structure evaluation have been revealed, including Latvian product quality evaluation taking into consideration share of products with high added value in the general export volume; and Latvian product competitiveness in different markets has been evaluated (see, for example: Balticexport, 2014; Investment and Development Agency, 2014; Pelece, 2014; Skribans, 2010; Benkovskis, 2008).

However, the opportunities to increase Latvian export volumes to the EU member states have not been explored thoroughly enough.

In this context, deeper and more thorough research of this export dimension and revealing the evaluation of export trade potential between Latvia and each particular EU state is topical.

The aim of this study is to measure and assess Latvia's export potential with the European Union countries based on the gravity model.

Study objectives are as follows:

1. To identify factors that influence the trade development among the EU countries.

2. To build a reasonable model for assessing the level of exports from Latvia to the EU (to develop a methodology).

3. To determine the estimated usage of trade relations with the EU in Latvia and to identify the existing potential of trade.

The present research uses mathematical, statistical, and econometric methods, such as regression analysis and gravity model.

The innovation aspect is related to the fact that the factors preventing the development of trade relations among the EU countries were added to the gravity model used for evaluation.

The data provided by the CSB of Latvia, Eurostat, Via Michelin Maps, the interactive database of world trade TradeMAP, 
and the Heritage Foundation study centre were used as the information base of this study.

The research data on foreign trade development and Latvian integration into the world's economy issues were used in the present paper. The data were issued by the Ministry of Economics of Latvia, the Bank of Latvia, Riga Technical University, and the Investment and Development Agency of Latvia (LIAA).

Scientific research dedicated to foreign trade problems, assessment of countries' trade cooperation potential, international integration, EU member state economy carried out by scientists such as J. Anderson and E. van Wincoop, O. Babecka-Kucharcukova, I. Gurova, L. Freinkman, and others has been used as the theoretical and methodological basis for the current paper.

\section{TheoreticAl BACKGROUND}

Various factors influence trade development among the countries. The classical theory of international trade based on the principle of comparative advantage provides the explanation of international specialisation as the international exchange cause (Vechkanov \& Vechkanova, 2008).

However, some factors that can significantly influence the trade among the countries as well as goods and geographic structures of foreign trade of a particular country are out of the analysis.

The empirical studies on this topic investigate various factors such as trading partners' economy size, their geographical remoteness, specifics of national rules of economic regulations, details on trade relations among countries, etc.

For example, when analysing the regional trade of CIS (12 countries) and detecting its intensity and potential, I. Gurova (2010) focused on factors such as Gross Domestic Product (GDP) that describes economy size and geographical distance between the trading countries that influences cost of transportation. Other factors have also been analysed (importing country population and exporting country population, per capita income of trading countries, availability of mutual land border, presence of mutual agreements, existence of the status of "the developing country with no access to the sea“"), but their importance for this study has not appeared to been essential (Gurova, 2010).

In the research dedicated to the assessment of CIS countries' trade potential with significant trading partners (149 countries), L. Freinkman and others have analysed such factors as trading countries' GDP, per capita income, distance between trading countries, common language, and presence of mutual agreements (Freinkman, Polyakov \& Revenco, 2004).

J. Anderson and E. van Wincoop have evaluated the influence of having barriers in trade with the world on the trade between two countries, pointing out that the more the given barrier, the greater the countries' willingness to have mutual trade (Anderson \& van Wincoop, 2003).

In the research dedicated to the issues on Russia's integration into the world's economy, O. Babetska-Kuharchukova and M. Morel, to evaluate trade potential of the country, used such factors as GDP and population of the trading countries (82 countries), currency exchange volatility, availability of mutual land border, costs of transportation, membership in the WTO and regional organisations. The authors put an emphasis on analysing the influence of various institutional characteristics of the countries such as the level of tariff and non-tariff barriers, fiscal pressure, monetary-credit policy, the degree of state's interference into price, salary, legislation, and property rights regulation, etc. on trade relations among the countries (Babetska-Kuharchukova \& Morel, 2004).

In the research paper that explores Armenia's export potential in neighbour states' markets (Turkey, Azerbaijan, Iran, Geogria), G. Airapetian and V. Airapetian have analysed the influence of the following factors on trade flows: GDP per capita in an exporting country and importing country; the distance between the trading countries; the presence of the common border; common language; colonial links between the trading countries; the presence of the sea border in one of both trading countries; WTO membership; membership in trade unions (Airapetian \& Airapetian, 2011).

I. Troekurova and K. Pelevina are the authors who use only GDP of counter agent states and their distance from the chosen exporting country, with a view to create a trade-economic integration model for BRICS states (Brazil, Russia, India, China, and South Africa). (Troekurova \& Pelevina., 2014).

To summarise the list of references devoted to empirical trade potential research issues among the countries, it is worth noting that:

1. There is no strict classification of the factors to be taken into consideration for trade relation analysis as well as there is no one single opinion shared by the authors as regards exceptional importance of particular factors. For example, some scientists suggest that the quality of institutional characteristics of the countries is more significant than other factors explaining the economic growth of the country, i.e. institutional environment provides conditions for economic growth. Other authors indicate that the economic growth can enhance institutional factors and broaden the country's international trade (Babetska-Kuharchukova \& Morel, 2004).

2. The list of factors taken for the analysis in various research papers is different because it depends on the list of trade relation participants and research goals.

3. In accordance with the authors, all the factors that influence trade relation development can be divided into two categories: supporting trade development and preventing trade development (trade barriers).

Most authors include trading countries' economy size usually measured in GDP into the first category.

The second category includes factors serving as barriers for the trade, which are the geographical distance between trading countries and presence of trade barriers (administrative, legislative, legal, currency, etc.).

The present paper aims to reveal the particular factors that influence trade flows among the EU states.

\section{Methodology Applied in the Research}

The evaluation of export potential between Latvia and the EU was carried out based on gravity model usage and calculating the coefficient of trade potential usage. 
Gravity model is widely used in empirical studies of international trade. The basic gravity model expresses the relation of trade volume between the countries to trading countries' gross domestic product (GDP) and distance between the countries (Shepherd, 2013):

$$
\ln X_{i j}=b_{0}+b_{1} \ln G D P_{i}+b_{2} \ln G D P_{j}+b_{3} \ln D_{i j}+\varepsilon_{i j},
$$

where $X_{i j}$ - the export volumes from the country $i$ to country $j$; $G D P_{i}, G D P_{j}$ - the gross domestic product (GDP) of the countries $i$ and $j ; D_{i j}$ - the distance between the countries $i$ and $j ; \varepsilon_{i j}$ - random error of regression; $b_{0}$ - the constant; $b_{1}, b_{2}, \ldots, b n$ - equation parameters.

There are different interpretations of the gravity model that take into consideration not only the factors used in the basic model, but also the influence of such factors as currency exchange volatility, the effect of presence of national borders (Anderson \& van Wincoop, 2003) or institutional factors affecting trade (Babetska-Kuharchukova \& Morel, 2004).

The present research adds the factors preventing the trade between countries to the basic model version.

Barriers that prevent trade development between the countries have been evaluated based on the index of economic freedom calculated by the Heritage Foundation, American research centre, for 186 countries.

The economic freedom is defined by the expert analysts of the Heritage Foundation as follows: "governments allow labour, capital and goods to move freely, and refrain from coercion or constraint of liberty beyond the extent necessary to protect and maintain liberty itself"' (The Heritage Foundation, 2014).

The index of economic freedom is based on 10 quantitative and qualitative factors, grouped into four broad categories, or pillars, of economic freedom:

Rule of Law (property rights, freedom from corruption);

Limited Government (fiscal freedom, government spending);

Regulatory Efficiency (business freedom, labour freedom, monetary freedom); and

Open Markets (trade freedom, investment freedom, financial freedom).

Each of the ten economic freedoms within these categories is graded on a scale from 0 to 100 , where 100 is the maximum freedom, while 0 is the minimum one, respectively. A country's overall score is derived by averaging these ten economic freedoms, with equal weight being given to each (The Heritage Foundation, 2014).

Barrier level has been defined for each country by expert analysts as the difference between the indicator of "full economic freedom", which is 100, and the index of economic freedom for a particular country published by the Heritage Foundation.

The gravity model evaluated in the present research can be expressed the following way:

$$
\ln X_{i j}=b_{0}+b_{1} \ln G D P_{i}+b_{2} \ln G D P_{j}+b_{3} \ln D_{i j}+b_{4} B_{i}+b_{5} B_{j},
$$

where $B_{i} u B_{j}$ - the level barriers for foreign trade development in the country $i$ and $j ; b_{1}, b_{2}, b_{3}, b_{4}, b_{5}$ - regression coefficient.
Regression coefficients are elasticities, while it is taken that $b_{1}>0, b_{2}>0$, and $b_{3}, b_{4}, b_{5}<0$.

The given gravity model allows calculating export volume from Latvia to the EU countries as conditioned by the factors included into the model. The indicator of export potential usage is calculated as follows:

$$
K_{X}=\frac{X_{\mathrm{fakt}}}{X_{i j}},
$$

where $K_{X}$ - the coefficient of export potential usage; $X_{\text {fact }}$ - the actual export volume; $X_{i j}$ - the export volume calculated as based on the model.

To define gravity model coefficients, the regression analysis has been carried out. Export volumes from Latvia to the EU countries and vice versa are taken as a dependent variable. Gross domestic product, the distance between the capitals of the trading states and trade relation development barrier levels are used as independent variables.

The analysis was based on the data issued for 2009, 2013 and 2014 as positive dynamics of Latvian export volumes without fluctuations caused by external general economic factors not taken into consideration in the present model had been observed since 2009 (see Fig. 1).

The basic data source on each EU member state's export was trade database entitled TradeMAP that provided the possibility to choose the exporting country and detect export volume.

To define the data on each country's gross national product (GNP), Eurostat database was used. This variable reveals the economy size of the trading states. The countries with higher GNP have more opportunities for trade than the ones with lower GNP.

For the distance between the countries under the analysis, the distance between their capitals was taken that was provided by Via Michelin Maps. Geographic distance between the states has a negative impact on mutual trade flows because of higher trade expenses caused by bigger distances. Despite the fact that the distance between the states is not the most reliable instrument for trade expense model, it is the distance that is pointed out in most theoretic and practical papers on foreign trade gravity models.

The information on the index of economic freedom of the countries under the present analysis needed for the evaluation of trade development barriers in 2009, 2013 and 2014 was taken from the data published by the American research centre, the Heritage Foundation.

\section{Research Limits}

To study the foreign trade of Latvia, a longer period of 1992 2014 has been reviewed to provide the comprehensive insight into foreign trade development from the beginning of Latvia's development as an independent country until 2014. The year 2014 is the last one under the analysis because of the availability of the statistical data on the moment of carrying out the present research.

To explore Latvian trade with the EU member states, a shorter period of 2007-2014 has been taken into consideration, as start- 
ing from the year 2007 statistical data on the EU states is issued for the most complete list of the EU members.

Trade potential evaluation has been made based on data for 2009, 2013 and 2014. The year 2009 reveals trade participants' position when overcoming the global financial crisis, the year 2013 is the year of expanding the European Union up to 28 members, with Croatia joining on 1 June 2013, whereas 2014 is the final year of the present research (restricted by data availability at the moment of the analysis).

The present paper investigates only the sector of trade of products that are exported (excluding export of services).

The present research is limited by a set of tasks and does not include the analysis of export trade structure to the countries with export potential as well as does not include selecting the products with the highest trade potential in these countries.

\section{General Characteristics of Foreign Trade Between Latvia AND The EU Countries}

Since Latvia has become independent, its foreign trade turnover has increased more than 14 times, which may signify that its integration into the global economy is quite successful. In accordance with the data issued by the Central Statistical Bureau of Latvia (CSB) for the period from 1992 to 2014, foreign trade is presented in Fig. 1.

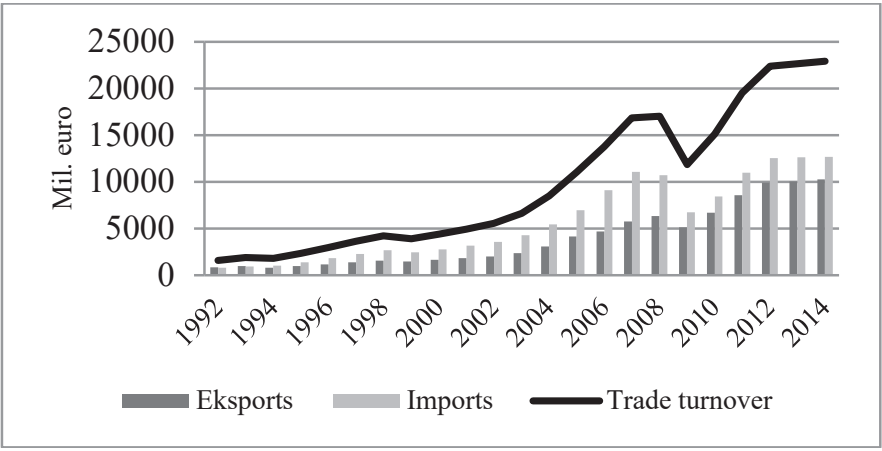

Fig. 1. Foreign trade dynamics of Latvia, million EUR (CSB of Latvia).

Good turnover volume of Latvia with world's countries in 2014 was EUR 22902.9 million, which was 21317.6 million more than in 1992 (EUR 1585.3 million). Foreign trade volume dynamics (see Fig. 1) signifies this economy factor's sensitivity to the environment where trade cooperation is formed. The initial fall was pointed out in 1994 as a result of financial and economic instability in Latvia (goods turnover decreased by $5 \%$ as compared to the previous year); the second one was in 1999 as a result of the economic crisis in Russia in 1998 (goods turnover decreased by $7 \%$ ); the third and the largest decrease took place in 2009 as a result of the global financial crisis in 2008 (goods turnover decreased by $30 \%$ ).

Despite the fact that the falls repeated from time to time (see Fig. 1), the average annual growth rate of Latvia's goods turnover in the period from 1992 to 2014 grew 1.14 times (or 114\%). However, in 2014, goods turnover increased insignificantly, i.e. just by $1 \%$ as compared to 2013 . Both export and import growth was slower.
Since 1994, import has been dominating in the foreign trade turnover structure and, as a result, there is a trade balance deficit. In accordance with the data issued by the Central Statistical Bureau of Latvia, it reached a peak of EUR 5321.5 million in 2007 and declined to EUR 2264 million in 2014 (see Table I).

TABLE I

Foreign Trade Balance of Latvia with the EU Countries, CIS and Others, Million EUR

\begin{tabular}{|l|c|c|c|c|c|c|c|c|}
\hline & $\mathbf{2 0 0 7}$ & $\mathbf{2 0 0 8}$ & $\mathbf{2 0 0 9}$ & $\mathbf{2 0 1 0}$ & $\mathbf{2 0 1 1}$ & $\mathbf{2 0 1 2}$ & $\mathbf{2 0 1 3}$ & $\mathbf{2 0 1 4}$ \\
\hline $\begin{array}{l}\text { EU } \\
\text { Countries }\end{array}$ & -4246 & -3516 & -1358 & -1595 & -2247 & -2816 & -2952 & -2648 \\
\hline CIS & -630 & -757 & -350 & -278 & -359 & -357 & 50 & 19 \\
\hline $\begin{array}{l}\text { Others } \\
\text { Countries }\end{array}$ & -446 & -136 & 132 & 141 & 158 & 531 & 289 & 365 \\
\hline Total & -5321 & -4409 & -1576 & -1732 & -2448 & -2641 & -2614 & -2264 \\
\hline
\end{tabular}

If the foreign trade balance is analysed in the context of three groups of countries: EU, CIS and other countries (countries in Asia, America, Australia), it can be seen that the foreign trade balance with the EU countries was negative from 2007 to 2014, while it was positive with CIS and other countries in 2013 and 2014, which allowed slightly decreasing the general deficit. It is suggested by the expert analysts of the Bank of Latvia that the improvement of the foreign trade balance has been a result of increasing competitiveness of Latvian enterprises as well as a result of new consumer markets found (Balticexsport, 2014).

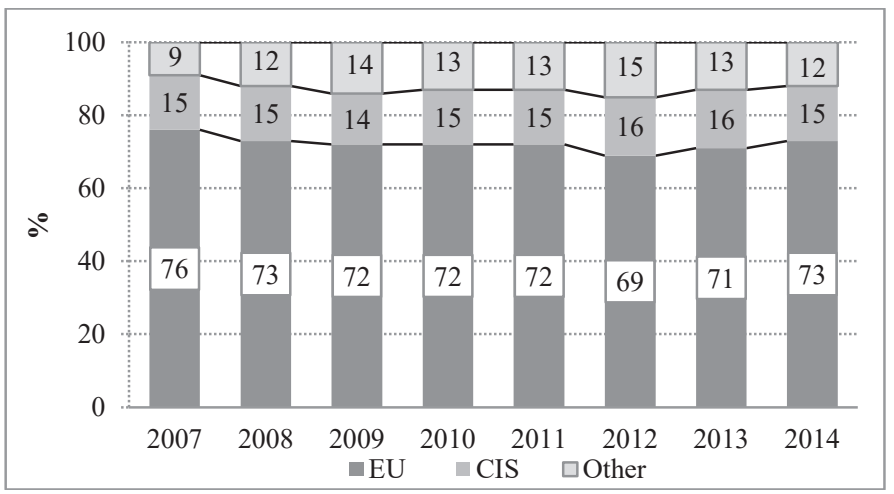

Fig. 2. Export structure of Latvian goods, for groups of countries, in \% (CSB of Latvia).

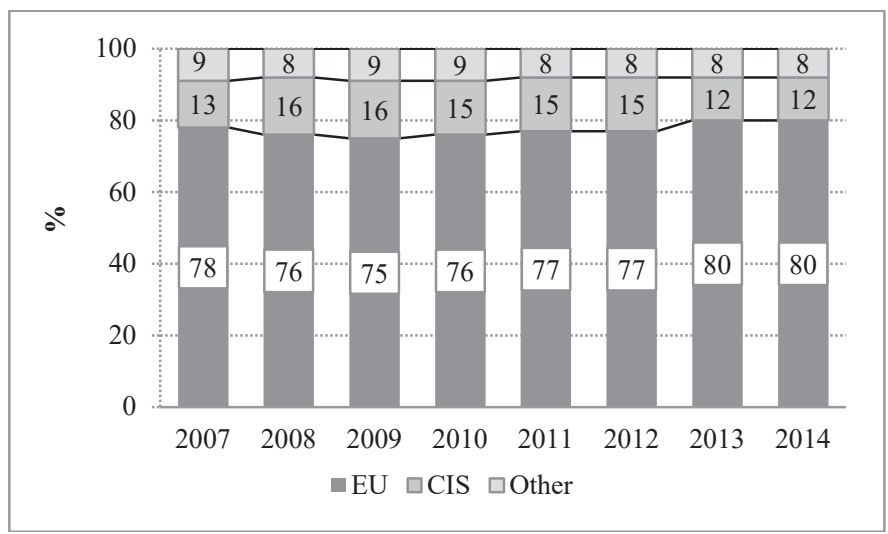

Fig. 3. Import structure of Latvian goods, for groups of countries, in \% (CSB of Latvia). 
The general trends in the export and import structure after 2007 are presented in Figs. 2 and 3.

Latvian share of export to the EU countries has been showing a decreasing trend (from $76 \%$ in 2007 to $73 \%$ in 2014). While the share of the EU in Latvian export has been decreasing, the share of other countries in the Latvian export has increased several times.

Latvian share of import from the EU countries has shown a growing trend during the study period, reaching its peak of $80 \%$ in 2013 and 2014, while import volume from CIS countries has declined to $12 \%$. Share of other states is insignificant.

The growth of export, which, according to many experts, is crucial for the economy of Latvia, will depend on the situation in the countries' consumer markets (Balticexport, 2014).

In accordance with the international statistics data, Latvian goods are exported to all the countries of the European Union.

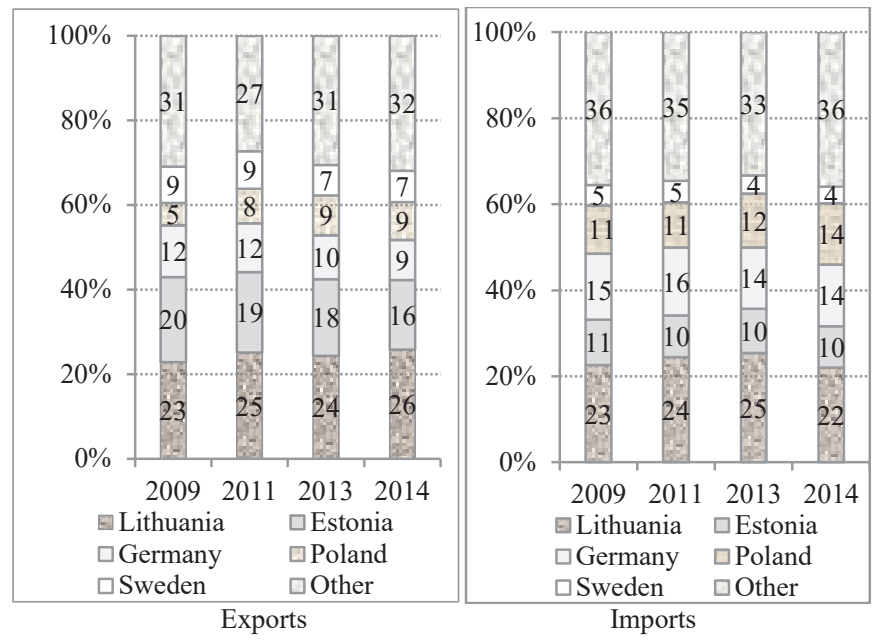

Fig. 4. Main trading partners of Latvia in the EU (Trade Map, 2014).

Figure 4 shows that, according to the data of 2014, the largest partners of Latvia, as regards export to EU countries, are Lithuania (26\%), Estonia (16\%), and Germany (9\%). In accordance with the world trade database Trade Map, the list of top-ten largest export partners includes Poland (9\%), Sweden (7\%), the United Kingdom (7\%), Denmark (5\%), Finland (3\%), the Netherlands (3\%), and France (2\%). The share of the rest 17 states is insignificant as it is less than $2 \%$ of the total export volume. Export volumes to most EU countries are increasing. In 2014, export volumes to Estonia, Germany, Denmark, Finland, the Netherlands and France were decreasing.

Also, Latvia imports products from all the European Union (Trade Map, 2014). In 2014, the largest volumes were imported to Latvia from Lithuania (22\%), Germany (14\%), Poland (14\%), and Estonia (10\%) (see Fig. 4). The list of top-ten largest import partners includes Finland (8\%), the Netherlands (5\%), Italy (5\%), Sweden (4\%), Denmark (3\%), and France (3\%). In spite of the growing import volumes from many European countries, import volumes from France, Belgium, Cyprus, and Crete are decreasing (Trade Map, 2014).

The most successful directions of Latvian foreign trade cooperation are those providing the country with the positive trade balance. Goods turnover dynamics of Latvia with the European countries and trade balance are represented in Table II.

TABLE II

Latvia's Goods Turnover Dynamics With the European Countries, Million EUR

\begin{tabular}{|c|c|c|c|c|c|c|c|c|}
\hline \multirow{2}{*}{$\begin{array}{c}\text { European } \\
\text { Union } \\
\text { countries }\end{array}$} & \multicolumn{4}{|c|}{$\begin{array}{c}\text { Turnover, } \\
\text { million EUR }\end{array}$} & \multicolumn{4}{|c|}{$\begin{array}{c}\text { Trade balance, } \\
\text { million EUR }\end{array}$} \\
\hline & 2009 & 2011 & 2013 & 2014 & 2009 & 2011 & 2013 & 2014 \\
\hline Lithuania & 1981 & 2081 & 4257 & 4135 & -296 & -521 & -823 & -309 \\
\hline Estonia & 1274 & 1999 & 2303 & 2187 & 206 & 349 & 241 & 243 \\
\hline Germany & 1220 & 2055 & 2159 & 2142 & -324 & -630 & -694 & -739 \\
\hline Poland & 762 & 1402 & 1907 & 2097 & -367 & -392 & -584 & -771 \\
\hline Sweden & 553 & 970 & 935 & 945 & 74 & 122 & 82 & 154 \\
\hline Denmark & 392 & 536 & 694 & 669 & 32 & 42 & 134 & 104 \\
\hline $\begin{array}{l}\text { United } \\
\text { Kingdom }\end{array}$ & 256 & 457 & 564 & 759 & 73 & 68 & 161 & 262 \\
\hline Finland & 386 & 775 & 850 & 961 & -93 & -246 & -322 & -557 \\
\hline Netherlands & 403 & 595 & 685 & 675 & -139 & -202 & -243 & -245 \\
\hline France & 267 & 387 & 404 & 407 & -76 & -138 & -102 & -106 \\
\hline Italy & 312 & 488 & 559 & 603 & -145 & -225 & -304 & -311 \\
\hline Belgium & 164 & 300 & 323 & 305 & -41 & -115 & -84 & -56 \\
\hline $\begin{array}{l}\text { Czech } \\
\text { Republic } \\
\end{array}$ & 138 & 230 & 286 & 329 & -59 & -97 & -67 & -43 \\
\hline Cyprus & 26 & 55 & 123 & 50 & -6 & 2 & 81 & 17 \\
\hline Spain & 145 & 186 & 220 & 309 & -36 & -56 & -106 & -38 \\
\hline Slovakia & 64 & 117 & 167 & 191 & -26 & -61 & -65 & -54 \\
\hline Austria & 111 & 149 & 197 & 207 & -36 & -90 & -121 & -125 \\
\hline Hungary & 110 & 141 & 143 & 203 & -72 & -92 & -93 & -64 \\
\hline Bulgaria & 17 & 31 & 43 & 46 & -4 & -6 & -6 & 1 \\
\hline Romania & 30 & 43 & 45 & 43 & 2 & 7 & -5 & 2 \\
\hline Greece & 11 & 15 & 21 & 27 & 1 & -2 & 2 & 7 \\
\hline Portugal & 12 & 14 & 26 & 45 & -3 & -6 & -3 & -16 \\
\hline $\begin{array}{l}\text { Luxem- } \\
\text { bourg }\end{array}$ & 12 & 12 & 26 & 22 & -7 & -8 & -8 & -2 \\
\hline Malta & 2 & 8 & 6 & 10 & 1 & 8 & 5 & 9 \\
\hline Ireland & 40 & 48 & 48 & 59 & 7 & -4 & -6 & -12 \\
\hline $\begin{array}{l}\text { Croatia } \\
(01.06 .2013) \\
\end{array}$ & 8 & 7 & 8 & 13 & -5 & -3 & -1 & -3 \\
\hline Slovenia & 27 & 35 & 46 & 48 & -19 & -27 & -30 & -29 \\
\hline Latvia, total & 8723 & 14701 & 17043 & 17485 & -1358 & -2327 & -2962 & -2682 \\
\hline
\end{tabular}

Table II presents the states where export dominates over import in the trade with Latvia and, as a result, the positive trade balance is formed. Out of the 4 largest trading partners (Lithuania, Estonia, Germany, and Poland), only one - Estonia - has the positive trade balance. The trade balance with Lithuania, Poland, and Germany is negative, which sufficiently leads to the negative balance for Latvia.

When trading with not so large partners such as Sweden, Denmark, the UK, Cyprus, Greece, Malta, Romania and Bulgaria, the positive trade balance is formed as well. However, the effect of these countries is not significant enough to improve foreign trade balance because of not large volumes of goods turnover.

As a result, reviewing the main trends of Latvian foreign trade development provides for drawing conclusions about the on-growing significance of the EU member states as Latvia's main trade partners. Also, taking into consideration the negative 
trade balance with the members of the European Union, the problem of the evaluation of Latvian export development opportunities to EU countries becomes increasingly topical.

Based on the gravity model, the research aimed to evaluate the trade potential of Latvia with each trade partner state that could help evaluate the unused opportunities to increase export to the EU member states.

\section{Assessment of Latvia’s Potential in The Trade With the EU Countries}

The present research offers the regression analysis of the spatial data (i.e. for a couple of countries per year) for the factors included into the model (1), for 2009, 2013 and 2014. As a result, the model of export volume evaluation has been designed for each year. The regression coefficients in the Latvian export model calculated with the help of the least-square method, are presented in Table III.

TABLE III

Regressing Export Statistics from Latvia to the EU Countries

\begin{tabular}{|l|c|c|c|}
\hline \multicolumn{1}{|c|}{ Coefficients } & $\mathbf{2 0 0 9}$ & $\mathbf{2 0 1 3}$ & $\mathbf{2 0 1 4}$ \\
\hline $\boldsymbol{b}_{\mathbf{0}}$ (the constant) & 15.00 & 13.93 & 12.89 \\
\hline $\boldsymbol{b}_{\mathbf{1}}$ (by GDPi) & 0.85 & 0.84 & 0.81 \\
\hline $\boldsymbol{b}_{\mathbf{2}}($ by GDPj) & 0.65 & 0.59 & 0.62 \\
\hline $\boldsymbol{b}_{\mathbf{3}}$ (by Dij) & -2.03 & -1.98 & -1.99 \\
\hline $\boldsymbol{b}_{\mathbf{4}}($ by Bi) & -0.02 & -0.01 & -0.002 \\
\hline $\boldsymbol{b}_{\mathbf{5}}$ (by Bj) & -0.06 & -0.02 & 0.00 \\
\hline $\begin{array}{l}\boldsymbol{R}_{\mathbf{2}}-\text { coefficient } \\
\text { of determination }\end{array}$ & 0.84 & 0.79 & 0.81 \\
\hline
\end{tabular}

The quantitative indicator of the model adequateness is the coefficient of determination $R_{2}$, the meaning of which for 2014 shows that $81 \%$ of export volumes are influenced by the chosen factors.

The coefficients with variables are in accordance with the hypothesis of the gravity model of the positive dependence of trade volumes on trade partners' economy size and negative dependence of trade volumes on partners' remoteness and presence of trade barriers. It should be noted that dependence on exporter state's GDP is stronger than that on importer state's GDP, which is signified by higher $b_{1}$ index value as compared to $b_{2}$ index. The negative dynamics of the coefficients (coefficient meaning decrease) shows that dependence of Latvian export volumes on the given factors is gradually weakening.

With the help of the econometric model, export volumes and export (trade) potential of Latvia with the EU states have been assessed in accordance with the factors included in the above-mentioned model.

The level of export potential usage is characterised by the export potential usage coefficient calculated in (3).

Table IV indicates the countries the coefficient of which in 2009, 2013 and 2014 was less than 1, i.e. export potential from Latvia to the below-mentioned states was not used.
TABLE IV

Export Potential Usage from Latvia to the EU Countries

\begin{tabular}{|l|c|c|c|}
\hline \multicolumn{1}{|c|}{ Countries } & $\mathbf{2 0 0 9}$ & $\mathbf{2 0 1 3}$ & $\mathbf{2 0 1 4}$ \\
\hline Finland & 0.18 & 0.25 & 0.18 \\
\hline Croatia (01.06.2013) & 0.24 & 0.19 & 0.20 \\
\hline Austria & 0.51 & 0.31 & 0.36 \\
\hline Slovenia & 0.53 & 0.44 & 0.42 \\
\hline Luxembourg & 0.19 & 0.39 & 0.45 \\
\hline Sweden & 0.69 & 0.59 & 0.60 \\
\hline Germany & 0.85 & 0.92 & 0.78 \\
\hline Greece & 0.85 & 0.88 & 0.81 \\
\hline Ireland & 0.96 & 0.92 & 1.04 \\
\hline Hungary & 0.74 & 0.48 & 1.12 \\
\hline Slovakia & 0.74 & 1.06 & 1.24 \\
\hline Czech Republic & 0.76 & 1.19 & 1.46 \\
\hline Denmark & 0.96 & 1.73 & 1.68 \\
\hline
\end{tabular}

Latvia has used its export potential with the countries having export usage potential index which is more than 1, i.e. actual export volumes to these territories are bigger than the ones included in the model.

Actual export volumes from Latvia to Lithuania and Estonia (biggest trade partners) are twice the volumes projected by the model of 2009, 2013 and 2014. Export potential usage index was 2.53 in 2009, 2.79 in 2013 and 2.78 in 2014 for Lithuania; while it was 2.63, 2.86 and 2.93 for Estonia, respectively. The given result can be explained by the trade connections developed through the years of partnership as well as by the effect of such factors as general culture, similar business environment, etc. It should be mentioned that, in accordance with the Central Statistical Bureau of Latvia, export volumes from Latvia to Lithuania and Estonia from 2009 to 2014 have grown by 2.27 and 1.6 times, respectively. This can be explained by the successful economic development of the above-mentioned countries, which resulted in the gross domestic product (GDP) growth by 1.27 times in Latvia, and by 1.40 times in Lithuania and Estonia, during the period from 2009 to 2014. This proves the gravity model hypothesis on the trade volumes positive dependence on trade states' economy size. In addition, in accordance with the index value as of GDP in 2014 (see Table III), when increasing the exporting country's GDP by $1 \%$, export volume grows by $0.81 \%$, while when increasing the importing country's GDP by $1 \%$ - by $0.62 \%$.

In general, the level of Latvia's export potential implementation in 2014 increased as compared to 2009, which was shown not only by positive coefficient dynamics for most countries, but also by a decreasing number of countries with the export potential usage coefficient from 13 to 8 (see Table IV). Latvia has not used its export potential with such countries as Finland, Croatia, Austria, Slovenia, Luxembourg, Sweden, Germany and Greece.

The above-mentioned analysis shows that even when having the economy size at the level of 2014, increasing export is possible and has potential to these countries. Therefore, it is necessary to analyse the opportunity to increase export into these states in the context of particular groups of products and to define the ones that have the highest potential for the Latvian economy. 


\section{Vi. Conclusion}

\section{Conclusions}

1. In Latvia, the total goods turnover has a growing trend. However, the growth became slower in 2013 and 2014.

2. Volumes of foreign trade operations are sensitive to changes in the economic and political situations.

3. Latvia manages export and import flows with all the European Union countries.

4. Most export volumes are implemented to Lithuania, Estonia, Germany, Poland, Sweden, Denmark, and the UK. The rest EU countries have the insignificant share: from $0.07 \%$ (Crete) to $2.90 \%$ (the Netherlands).

5. Export volumes to most European countries are increasing. Export volumes to Estonia, Germany, Denmark, Finland, the Netherlands and France are decreasing.

6. Most import volumes are delivered to Latvia from Lithuania, Germany, Poland, Estonia and Finland. The rest importing countries have the insignificant share: from $0.01 \%$ (Malta) to $4.56 \%$ (the Netherlands).

7. Import volumes from most European states to Latvia are growing. Import volumes from Lithuania, Estonia, Sweden and the Netherlands are declining.

8. Trade balance with the most important export partners, in terms of export volumes, (Lithuania, Poland, Germany, Finland and the Netherlands) is negative, which has a significant impact on a negative foreign trade balance index for Latvia.

9. Having reviewed the basic trends of Latvian foreign trade development, it can be concluded that the EU member states are to be retained as the main trading partners of Latvia in the future, which makes export development to these countries more essential.

10. The model designed to define the level of export from Latvia to the EU countries has confirmed that the size of trading countries' economy has a positive effect on export volumes from Latvia to the EU countries, while geographical remoteness and the existing barriers preventing trade relation development have a negative effect.

11. The level of export potential implementation has positive dynamics. However, in 2014, Latvia did not reach the level of export conditioned by economy volumes of partner countries with eight countries: Finland, Croatia, Austria, Slovenia, Luxembourg, Sweden, Germany and Greece.

12. With the states, with which Latvia has used its export potential (Lithuania, Estonia, etc.), export volumes can be increased provided that the economies of Latvia and these countries develop (GDP growth) and foreign trade barriers between them decrease.

\section{Proposals}

1. The model that has been worked out can be recommended for using to assess export potential of the European Union member states in future as the given model provides the appropriate result validity.
2. It is suggested to introduce the list of countries having export potential with Latvia that has been compiled in the process of the present research to organisations involved in Latvian export development problems.

3. The present research paper needs to be continued by detecting the products having potential for being exported to each of the states, with which Latvia has not used its export potential. This can be of interest to Latvian exporters and help developing Latvian export in general.

\section{REFERENCES}

Anderson, J., van Wincoop E. (2001). Gravity with gravitas: A solutions for the border puzzle, (NBER Working paper No 8079), Cambridge, Retrieved July 2, 2014, from: http://www.nber.org/papers/w8079.pdf?new_window=1

Babecka Kucharcukova, O., Morel, M., (2004). The role of market institutions in the process of Russia's integration into the world economy. HSE Economic Journal, 2. Retrieved March 17, 2014, from http://ecsocman.hse.ru/ data/503/137/1231/08_02_03.pdf

Babecka Kucharcukova, Ō., Babecky J., Raiser, M. (2010). A Gravity Approach to Modelling International Trade in South-Eastern Europe and the Commonwealth of Independent States: The Role of Geography, Policy and Institutions, Working paper, Czech National Bank, Retrieved July 9, 2014, from http://www.cnb.cz/miranda2/export/sites/www.cnb.cz/en/research/research_ publications/cnb_wp/download/cnbwp_2010_04.pdf

Balticexsport (2014). Latvijas ārējā tirdzniecība. Retrieved May 6, 2014, from http://balticexport.com/?article=latvijas-areja-tirdznieciba\&lang=lv

Beņkovskis, K., Davidsons, G., \& Vitola, K. (2008). Latvijas eksporta nākotnes struktūra. Retrieved from the website: http://www.bank.lv/public files/images/img lb/izdevumi/latvian/avrev/2008/averss 2008 2.pdf

Cabinet of Ministers of the Republic of Latvia, (2013, Jan. 17) Regulation Nr. 249 Latvijas preču un pakalpojumu eksporta veicināšanas un ārvalstu investīciju piesaistes pamatnostādnes 2013.-2019. gadam. Retrieved July 15, 2014, from http://likumi.lv/doc.php?id=257597

Eurostat (2014). Intra-EU27 trade. Retrieved July 11, 2014, from http://epp. eurostat.ec.europa.eu/statistics_explained/index.php/International_trade_ in goods

Freinkman, L., Polyakov, E., Revenco, C. (2004). Trade Performance and Regional Integration of the CIS Countries. World Bank Working Papers (38). The World Bank. Washington. Retrieved July 11, 2014, from http://dx.doi. org/10.1596/0-8213-5896-0

Gurova, I. (2010). Regional trade of the CIS "gravity model". Results of the project №08-02-00313a "Regional trade and economic integration of the CIS". Ulyanovsk State University. Retrieved May 23, 2014, from www.econorus. org/consp/files/guad.doc

Integration Research Center of Eurasian Development Bank. (2014). Quantitative analysis of the economic integration of the European Union and the Eurasian Economic Union: methodological approaches. Retrieved July 15 from: http://www.eabr.org/r/research/centre/projectsCII/

Investment and Developement Agency of Latvia. (2014). Eksporta tirgi. Retrieved from the Investment and Developement Agency website http://www. liaa.gov.lv/lv/eksportetajiem/eksporta-tirgi.

Ministry of Economy of the Republic of Latvia. Nozares politika. Starptautiska sadarbība. Retrieved August 18, 2014, from https://em.gov.lv/lv/nozares_politika/starptautiska_sadarbiba/

Michelin route planner and maps. Retrieved July 15, 2014, from http://www. viamichelin.com

Pelece, D. (2014). Latvijas preču eksports škērsgriezumā. Retrieved from http:// www.makroekonomika.lv/latvijas-precu-eksports-skersgriezuma

Shepherd, B., (2013). The gravity model of international trade: A user guide. ARTNeT Gravity Modeling Initiative, UN

Skribans, V. (2010). Estimation of Economic Benefit of the Introduction of Latvia in the European Union. Munich Personal RePEc Archive. Riga Technical University. Retrieved Dec. 15, 2014 from

http://mpra.ub.uni-muenchen.de/29313/1/MPRA_paper_29313.pdf

Statistics of the World Bank, (2014). Gross domestic product ranking table. Retrieved July 15, 2014, from http://www.worldbank.org/

The Heritage Foundation, (2014). Index of Economic Freedom. Retrieved July 12, 2014, from http://www.heritage.org/index/about

Trade Map, (2014). Trade statistics for international business development. Retrieved Dec. 12, 2015, from http://www.trademap.org/Index.aspx

Vechkanov, G., Vechkanova, G., (2008). Macroeconomics. SPb., PITER, Retrieved June 25, 2014, from: http://www.alleng.ru/d/econ/econ249.htm 


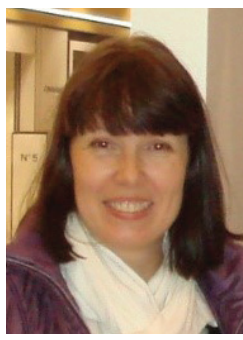

Ērika Pančenko graduated from Riga Polytechnic Institute in 1984, and in 1993 received Dr. sc. ing. degree. She graduated from RISEBA and received a Master of Business Administration (MBA) degree in 2004.

After graduation, she worked at private firms, had experience in managing her own business. Since 2002 she has been working at RISEBA as an Assistant Professor. She conducts scientific research, participates in research projects for the LR Competition Council, LR Ministry of Economy and LR Ministry of Agriculture. Current research includes the analysis of Latvia's export potential with different countries.

E-mail: erika.pancenko@riseba.lv

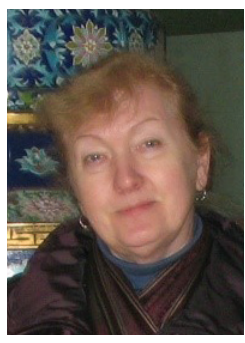

Tatjana Ivanova graduated from Riga Aviation Institute, the Faculty of Economics in 1977 and in 1984 received Dr. oec. degree (Leningrad Institute of Finance and Economics).

After graduation, she worked as an Accountant and Chief Accountant at private companies. Since 1996 she has been working at RISEBA as an Assistant Professor. She conducts scientific research, participates in research projects for the LR Competition Council, LR Ministry of Economy and LR Ministry of Agriculture. Current research includes the analysis of Latvia's export potential with different countries.

Major publications of authors:

Jasjko, D., Kantane, Z., Pancenko, E., Ivanova, T. (2012). Latvian-Turkish economic cooperation: Future perspectives for business extension", LLU collection of articles, 29, 89-95 (EBSCO database).

Pancenko, E., Jasjko, D., Ivanova, T. (2011). Determination of the transit potential of Latvia in the trade between Turkey and the EU, Journal of Business Management, 4, 142-150.

Jasjko, D., Pancenko, E., Ivanova, T. (2011). Latvian Maritime Transport sector: Opportunities for Latvian-Turkish trade cooperation, Journal of Business Management, 4, 151-161.

E-mail: tatjana.ivanova@riseba.lv 